\title{
The induction of myeloma cell death and DNA damage by tetrac, a thyroid hormone derivative
}

\author{
Keren Cohen 1,2,3, Uri Abadi1,3, Aleck Hercbergs ${ }^{4}$, Paul J Davis ${ }^{5}$, Martin Ellis ${ }^{1,3}$ and Osnat Ashur-Fabian1,2,3 \\ ${ }^{1}$ Translational Hemato-Oncology Laboratory, The Hematology Institute and Blood Bank, Meir Medical Center, Kfar-Saba, Israel \\ 2Department of Human Molecular Genetics and Biochemistry, Tel Aviv University, Tel Aviv, Israel \\ ${ }^{3}$ Sackler Faculty of Medicine, Tel Aviv University, Tel Aviv, Israel \\ ${ }^{4}$ Radiation Oncology, Cleveland Clinic, Cleveland, Ohio, USA \\ ${ }^{5}$ Department of Medicine, Albany Medical College, Albany, New York, USA
}

Correspondence should be addressed to O Ashur-Fabian: osnataf@gmail.com

\begin{abstract}
Multiple myeloma (MM) is a plasma cell malignancy in which involvement of the thyroid hormone-integrin $\alpha v \beta 3$ pathway was shown, and pharmacologic inhibition of this pathway is a rational approach to disease management. A thyroid hormone derivative, tetraiodothyroacetic acid (tetrac), which inhibits L-thyroxine $\left(T_{4}\right)$ and 3,5,3'-triiodo-Lthyronine $\left(\mathrm{T}_{3}\right)$ binding to $\alpha \mathrm{v} \beta 3$ integrin, was studied in five MM cell lines and primary bone marrow (BM) MM cells. Tetrac inhibited MM cell proliferation (absolute cell number/viability) and induced caspase-dependent apoptosis (annexin-V/PI and cell cycle). Activation of caspase- 9 and caspase- 3 was further demonstrated. Moreover, DNA damage markers, ataxia-telangiectasia-mutated (ATM) kinase, poly ADP-ribose polymerase (PARP-1) and histone $\gamma \mathrm{H} 2 \mathrm{AX}$ were induced by tetrac. The various tetrac-initiated effects were attenuated by Arg-Gly-Asp (RGD) peptide, suggesting integrin involvement. Primary BM mononuclear cells were harvested from MM patients $(n=39)$ at various disease stages. Tetrac-induced apoptosis (12/17 samples) and sensitized the cytotoxic action of bortezomib (6/9 samples). Lastly, expression of plasma membrane integrin $\alpha \mathrm{v} \beta 3$ was shown not only in the malignant plasma clone, but also in other cell populations within the BM samples $(n=25)$. Tetrac is anti-proliferative and pro-apoptotic in MM and cells may offer a therapeutic approach for this disease.
\end{abstract}

\author{
Key Words \\ - integrin \\ - myeloma \\ - thyroid hormone derivatives
}

\section{Introduction}

A large number of epidemiological and human studies have demonstrated an association between thyroid hormone and cancer. In patients with elevations of serum thyroid hormone, an increased risk of cancer compared with euthyroid patients has been reported (Ness et al. 2000, Hellevik et al. 2009). An association between thyroid dysfunction and the risk of development of multiple myeloma (MM), a plasma cell (PC) malignancy accounting for more than $13 \%$ of hematological malignancies, has also been suggested (Dalamaga et al. 2008). Another body of epidemiological and clinical evidence suggests improved survival in individuals with a variety of cancers who also have hypothyroidism (Cristofanilli et al. 2005, Nelson et al. 2006, Illouz et al. 2009, Baldazzi et al. 2010, Hercbergs et al. 2010, Schmidinger et al. 2010). A few years ago, a binding site for the thyroid hormones 
L-thyroxine $\left(\mathrm{T}_{4}\right)$ and 3,5,3'-triiodo-L-thyronine $\left(\mathrm{T}_{3}\right)$ was described on $\alpha v \beta 3$ integrin (Bergh et al. 2005). This integrin is overexpressed in an array of cancer types (Desgrosellier \& Cheresh 2010), including MM (Vacca et al. 2001, Ria et al. 2002, Tucci et al. 2009). The affinity of the receptor is higher for $\mathrm{T}_{4}$ than for $\mathrm{T}_{3}$ (Bergh et al. 2005), and binding of $\mathrm{T}_{4}$ occurs at physiological free $\mathrm{T}_{4}$ levels. The cell surface receptor-binding site for thyroid hormones on integrin $\alpha v \beta 3$ is located in close proximity to the well-investigated Arg-Gly-Asp (RGD) recognition site. This region of $\alpha v \beta 3$ contains receptors for other small molecules in addition to thyroid hormone that do not contain an RGD sequence and thus are 'nonRGD' binding sites. This thyroid hormone-binding site has been studied by crystallography and mathematical modeling of the thyroid hormone-binding kinetics (Aghajanova et al. 2011). The site has no structural homologies with the nuclear thyroid hormone receptors (TRs) that mediate genomic actions of the hormone. The description of a cell surface receptor binding site that is unrelated to conventional nuclear TRs has served to define the contributions of non-genomic actions of thyroid hormones to cancer. Upon binding of either hormone to the integrin, numerous effects are exerted by activating several signaling pathways (Davis et al. 2011). Although the thyroid hormone-integrin axis has been shown to be present in an array of tumor types, our group suggested a role for this pathway in a hematological malignancy, MM. This was confirmed by showing an increase in cell proliferation and activation of MAPK by $\mathrm{T}_{3} / \mathrm{T}_{4}$ via the $\alpha \mathrm{v} \beta 3$ integrin (Cohen et al. 2011). In this current work, we have characterized the effects of an antagonist at the hormone receptor site on the integrin, tetraiodothyroacetic acid (tetrac). Tetrac is a naturally occurring thyroid hormone derivative with low-potency thyromimetic activity inside the cell at TRs, but that selectively blocks binding of $\mathrm{T}_{4}$ and $\mathrm{T}_{3}$ to the thyroid hormone receptor site on $\alpha v \beta 3$ (Davis et al. 2011,2016 ). This agent was shown by in vitro and animal models to reduce cancer cell proliferation, cell migration and angiogenesis (Mousa et al. 2008, 2012, Rebbaa et al. 2008, Yalcin et al. 2009), to induce apoptosis in tumor cells (Glinskii et al. 2009, Yalcin et al. 2010) and to foster DNA double-strand breaks (Hercbergs et al. 2011). Tetrac has also been shown to chemosensitize several cancer cells that express chemoresistance (Rebbaa et al. 2008). Despite this extensive research in solid tumor models, tetrac has never been studied as a potential therapeutic agent in MM.

\section{Methods and materials}

\section{Cell lines and primary BM cells}

MM cell lines: CAG and ARK (established at the Arkansas Cancer Research Center), RPMI-8226 (CCL 155, ATCC), U266 (TIB-196, ATCC) and ARP-1. All cell lines were negative for mycoplasma contamination. Bone marrow (BM) aspirates were obtained upon written consent from a total of 40 patients at various disease stages (clinical data are presented in Supplementary Table 1, see section on supplementary data given at the end of this article). Additionally, one normal BM sample from healthy subject was collected. All BM aspirates were obtained from patients treated at the Meir Medical Center after approval by an Institutional Review Board (IRB number \#180-2010). BM mononuclear cells were isolated by Ficoll-Paque gradient centrifugation according to the manufacturer's instructions (Sigma-Aldrich). The different mononuclear cell populations were characterized and immunophenotyping was performed by flow-cytometry. Cells were grown in RPMI-1640 medium supplemented with $10 \%$ heat-inactivated FCS, penicillin and streptomycin antibiotics and the passage number for the experiments described was up to 20 .

\section{Reagents and chemicals}

$\mathrm{T}_{3}, \mathrm{~T}_{4}$ and tetrac (Sigma-Aldrich) were dissolved in DMSO to $100 \mathrm{mM}$ and further dissolved in $1 \mathrm{mM} \mathrm{KOH}$-propylene glycol, which was also used as a vehicle control (final concentration of $0.04 \mathrm{~N} \mathrm{KOH}$ with $0.4 \%$ polyethylene glycol (vol/vol)). RGD and Arg-Gly-Glu (RGE) peptides (Sigma-Aldrich) were dissolved at $100 \mathrm{mM}$ in PBS. Bortezomib (dissolved in saline to $2.6 \mu \mathrm{M}$ ) was obtained from the oncology pharmacy at Meir Medical Center. The volume of solvent added to each well has been kept constant for all conditions. Pan-caspase inhibitor, Z-VADFMK was purchased from Enzo Life Sciences (Farmingdale, NY, USA). Monoclonal antibody against $\alpha v \beta 3$ integrin (LM609, PE/FITC-conjugated) was from Chemicon International. APC-CD138 antibodies were from Miltenyi Biotec (Bergisch Gladbach, Germany), FITC-CD45 and PE-CD38 antibodies were from BioLegend, San Diego, CA, USA. Proliferating cell nuclear antigen (PCNA) antibody was from Santa Cruz Biotechnology. Antibodies against total and cleaved caspase-9, caspase-3, PARP-1 and tubulin were from Cell Signaling. Anti-AIF was from EMD Millipore. Anti-pATM (phospho-serine 1981) was from Epitomics (Burlingame, CA, USA) and anti-p $\gamma \mathrm{H} 2 \mathrm{AX}$ 
(phospho-serine 139) from Chemicon International. All antibodies were appropriately validated.

\section{WST-1 proliferation assay}

WST-1 reagent (Roche; 10\% final concentration) was incubated according to the manufacturer's instructions as previously described (Cohen et al. 2015).

\section{Flow-cytometry}

Absolute cell number: cells were harvested in a fixed volume and counted. Cell cycle: following permeabilization and fixation by incubation with $70 \%$ ethanol $\left(20 \mathrm{~min},-20^{\circ} \mathrm{C}\right)$, the cells were stained with DNA propidium iodide (PI) $(50 \mu \mathrm{g} / \mathrm{mL})$ for $15 \mathrm{~min}$ at room temperature, along with RNAse A $(10 \mu \mathrm{g} / \mathrm{mL})$ (Sigma-Aldrich) and cell cycle analysis was carried out by flow-cytometry (MACSQuant, Miltenyi Biotec). Apoptosis/necrosis: apoptotic cell death was measured by annexin-V/PI assay (BioVision) as previously described (Shinderman-Maman et al. 2016). Immunophenotype: immunophenotyping was performed in BM-derived mononuclear cells by using FITC-CD45, PE-CD38 (data not shown) and APC-CD138 antibodies. $\alpha v \beta 3$ expression: cell lines and primary BM cells were harvested in RPMI-1640 medium and labeled with $10 \mu \mathrm{g} / \mathrm{mL}$ FITC- $\alpha \mathrm{v} \beta 3$ or PE- $\alpha \mathrm{v} \beta 3$ antibody (LM609).

\section{RNA extraction and cDNA synthesis}

RNA was extracted using a NucleoSpine RNA II kit (Macherey-Nagel, Duren, Germany) according to the manufacturer's instructions and eluted in $40 \mu \mathrm{L}$ RNasefree water, as previously described (Cohen et al. 2015). RNA concentration and purity were measured using a NanoDrop 1000 Spectrophotometer (Thermo Scientific). 200 ng RNA were reverse transcribed using a High-Capacity cDNA Reverse Transcription Kit (Applied Biosystems), according to the manufacturer's instructions.

\section{Real-time PCR}

Complementary DNA (cDNA) was analyzed for the following apoptotic genes: Apoptotic protease activating factor-1 (apaf1, accession number Nm_013229), caspase-3 (accession number Nm_004346), p53-upregulated modulator of apoptosis (PUMA, accession number Nm_014417), NOXA (accession number Nm_021127) and FAS (accession number Nm_000043), by 7500 Fast Real-Time PCR system (Applied Biosystems), using Applied Biosystems Fast Sybr Green Mix (cat \# 4385612).
Results, normalized to beta actin (accession number Nm_001101), were calculated as -fold change, using the comparative threshold cycle method $\left(2^{-\Delta \Delta C T}\right)$ relative to control cells (i.e., controls were assigned a value of 1 by definition). Primers (Hylabs, Rehovot, Israel) were designed as published before (Cohen et al. 2011) in different exons in order to eliminate DNA contamination, using Primer-Express software (Applied Biosystems). Different bioinformatics tools, including BLAST and alignment PCR analysis, were used to design primers suitable for the amplification of fragments from the candidate genes. Primers sets were Apaf1: F TGCGCTGCTCTGCCTTCT, R: CCATGGGTAGCAGCTCCTTCT. Caspase 3: F: CAGACAGTGGTGTTGATGATGAC, R: TCGCCAAGAATAATAACCAGGTG. Puma: F: GAAGAGCAAATGAGCCAAACG, R: GGAGCAACCGGCAAACG. Noxa: F: CGGAGATGCCTGGGAAGAA, R: CCAAATCTCCTGAGTTGAGTAGCA. Fas: F: CCCTCCTACCTCTGGTTCTTACG, R: TGATGTCAGTCACTTGGGCATT. Beta actin: $\mathrm{F}$ : CCTGGCACCCAGCACAAT, R: GCCGATCCACACGGAGTACT.

\section{Western blotting}

Equal numbers of cells (106 cells/6-well plate) were used for total protein extraction quantified by BCA Protein

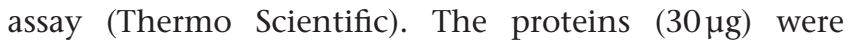
separated on 10-12.5\% polyacrylamide gels, transferred to PVDF membranes and analyzed by Western blot, using primary antibodies and appropriate second HRP-conjugated antibody (Jackson Immuno-Research Laboratories). Immunoreactive proteins were detected by chemiluminescence reagents (Biological Industries, Beit Haemek, Israel). Alpha tubulin or beta actin was used for normalization. Band intensity was visualized using LAS3000 (FujiFilm, Tokyo, Japan) and quantified by Multigauge, v3.0 software and normalized to protein amount.

\section{Inhibition of caspase-dependent apoptosis}

MM cells were treated in the presence/absence of $50 \mu \mathrm{M}$ pan-caspase inhibitor, Z-VAD-FMK, dissolved in DMSO.

\section{Statistical analysis}

Mean \pm S.D. was calculated for each value. In order to compare the means for pairs of groups (treatment vs control), Student's unpaired t-test was used. A value of $P<.05$ was considered significant. 


\section{Results}

Tetrac inhibits MM cell proliferation and viability and induces apoptosis

We have previously demonstrated in MM cell lines that the activation of pERK by the thyroid hormones is effectively inhibited by tetrac (Cohen et al. 2011). Additional experiments indicated that the reduction of apoptotic genes, mainly by $\mathrm{T}_{4}$, was reversed in the presence of tetrac (Supplementary Fig. 1). These anti-mitogenic actions were further explored in four MM cell lines (U266, ARK, RPMI8226 and CAG). The cells were seeded (100,000/96-well plate) and treated daily with increasing concentrations of tetrac $(10,50$ and $100 \mu \mathrm{M})$ for $24-96 \mathrm{~h}$. At each time point, cell proliferation was estimated by WST-1 proliferation assay (Fig. 1A) and cell counts (Fig. 1B). Tetrac reduced MM cell proliferation by $50-75 \%$ in all cell lines tested, in a time/dose manner that was cell specific. In parallel, a reduction in the absolute cell number, starting at $48 \mathrm{~h}$, was documented in all of the cell types.

Apoptosis analysis (annexin-V/PI, Fig. 1C) further indicated a time-dependent reduction in cell survival (An-/PI-) with a maximal effect after $72 \mathrm{~h}$ of $50 \mu \mathrm{M}$ tetrac (35-63\%) and $100 \mu \mathrm{M}$ tetrac (76-90\%). In parallel, an increase in apoptosis in response to $50-100 \mu \mathrm{M}$ tetrac for 24-96h was shown (Fig. 1D). The percentage of cells in early apoptosis (An+/PI-) and late apoptosis/necrosis $(\mathrm{An}+/ \mathrm{PI}+, \mathrm{An}-/ \mathrm{PI}+)$ are presented as $\%$ of apoptotic cells. Representative annexin-V/PI results for RPMI-8226 cells and CAG are depicted in Supplementary Fig. 2A and B, respectively. Induction in SubG1, indicative of apoptosis, was further shown by cell cycle analysis (Fig. 1E). A representative cell cycle histogram for RPMI-8226 cells is presented in Supplementary Fig. 2C.

\section{Tetrac activates caspases, but not AlF, in MM cell lines}

To assess whether the induction in apoptosis involved the activation of caspases, RPMI-8226 cells ( $10^{6}$ cells/6-well plate) were treated with increasing tetrac concentrations $(1-50 \mu \mathrm{M})$ for $1-8 \mathrm{~h}$. Doxorubicin $(1 \mu \mathrm{M})$ served as a positive control. Cleavage of caspase- 3 , caspase- 9 and PARP-1, normalized to the non-cleaved form, as well as AIF levels, were analyzed by Western blots. In details, representative blots (Fig. 2A) indicate that cleavage of caspase-9 was induced following $1-4 \mathrm{~h}$ of incubation with $1 \mu \mathrm{M}$ tetrac, as well as after $8 \mathrm{~h}$ in the presence of $50 \mu \mathrm{M}$ tetrac concentration. Caspase- 3 cleavage was completely absent at $1-2 \mathrm{~h}$, while following an incubation of $4 \mathrm{~h}$ with $1 \mu \mathrm{M}$ tetrac, an induction was observed. This effect was sustained at $8 \mathrm{~h}$ of treatment at all concentrations examined. No significant effect on PARP-1 level was observed. Results in additional four MM cell lines are presented in Supplementary Fig. 3. The levels of apoptosisinducing factor (AIF), a caspase-independent apoptosis marker, were unchanged (Fig. 2B). The calculated results following tetrac incubations are presented in Fig. 2C.

\section{Characterizing involvement of $\mathrm{p} 53$ and caspases in action of tetrac in MM}

After observing that caspases were induced by tetrac, we determined whether tetrac activities were caspase dependent, using a pan-caspase inhibitor, Z-VAD-FMK. In addition, p53 involvement was studied using RPMI8226 p53-temperature-sensitive cells, which express wildtype p53 at permissive $\left(32^{\circ} \mathrm{C}\right)$ and mutant p53 (E285K) at restrictive $\left(37^{\circ} \mathrm{C}\right)$ temperatures (Teoh et al. 2000, Hu et al. 2015). The cells were treated with tetrac $(50 \mu \mathrm{M})$ in the presence/absence of Z-VAD-FMK $(50 \mu \mathrm{M})$ at $32^{\circ} \mathrm{C}$ and $37^{\circ} \mathrm{C}$ for $96 \mathrm{~h}$ and were first assessed for cell proliferation by WST-1 (Fig. 3A) and cell counting (Fig. 3B). At restrictive temperature $\left(37^{\circ} \mathrm{C}\right.$, mutated p53), tetrac reduced cell proliferation (Fig. 3A, black bars) and cell number (Fig. 3B, black bars) by about 0.5 -fold. This effect was not reversed by Z-VAD-FMK. Similar results (Fig. 3A and B, gray bars) were observed under permissive temperature $\left(32^{\circ} \mathrm{C}\right.$, wild-type p53). When comparing the effect of tetrac on cell proliferation under both p53 conditions it appeared that tetrac's effect was more significant in the absence of wild-type p53 (Fig. 3A, marked by \#). This effect was not reversed by Z-VAD-FMK in both permissive $\left(32^{\circ} \mathrm{C}\right.$, wild-type p53) and restrictive $\left(37^{\circ} \mathrm{C}\right.$, mutant $\left.\mathrm{p} 53\right)$ temperatures.

Next, cell death was determined by performing annexin-V/PI and cell cycle assays (flow-cytometry). Results (Fig. 3C) indicated that in cells bearing mutant p53 $\left(37^{\circ} \mathrm{C}\right.$, black bars), as well as in cells containing wild-type p53 $\left(32^{\circ} \mathrm{C}\right.$, gray bars), tetrac induced about a 3 -fold increase in apoptotic cell death. A comparison of the apoptotic effect of tetrac between the two temperatures, depicted a greater significant effect in p53-independent cells (Fig. 3C, marked by \#). Induction of cell death was partially inhibited by Z-VAD-FMK. Representative annexin-V/PI results for RPMI-8226 cells are depicted in Supplementary Fig. 4A.

Cell cycle analysis indicate that in cells lacking wild-type p53 $\left(37^{\circ} \mathrm{C}\right.$, Fig. 3D), a potent increase in SubG1 was obtained with tetrac and was reversed by Z-VAD-FMK. However, in cells containing wild-type p53 $\left(32^{\circ} \mathrm{C}\right.$, Fig. $\left.3 \mathrm{E}\right)$, a parallel increase in S-G2M arrest was 
— Control - Tetrac $10 \mu \mathrm{M}$ - Tetrac $50 \mu \mathrm{M}$ — Tetrac $100 \mu \mathrm{M}$

A
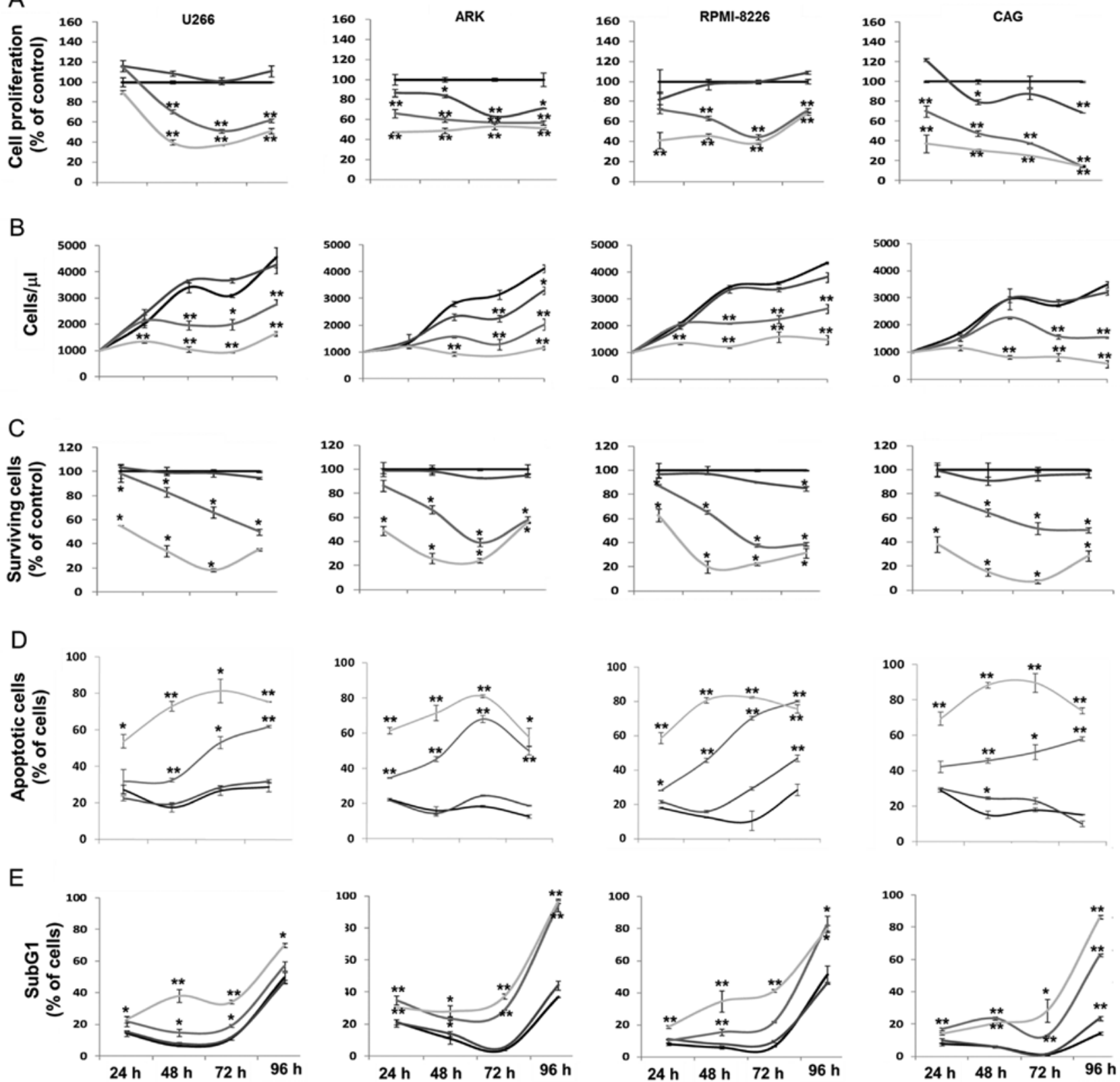

Figure 1

Tetrac inhibits MM cell proliferation and viability and induces apoptosis. Four MM cell lines were treated with increasing concentrations of tetrac $(10-100 \mu \mathrm{M})$ for 24-96h and evaluated for (A) Cell proliferation (WST-1, ELISA), (B) cell number (flow-cytometry), (C and D) apoptosis (Annexin-V/PI) and (E) cell cycle, by flow-cytometry. Experiments were repeated three times in triplicate. ${ }^{\star} P \leq 0.05,{ }^{*} P \leq 0.01$.

shown. Representative cell cycle results are depicted in Supplementary Fig. 4B.

\section{Tetrac increases DNA damage response markers in MM cells}

Many cytotoxic antagonists lead to cell death via their effect on DNA damage response (DDR). We evaluated by Western blotting the effect of tetrac on levels of three central DDR protein markers, phosphorylated ataxiatelangiectasia mutated (pATM), PARP- 1 and histone $\gamma \mathrm{H} 2 \mathrm{AX}$, in RPMI-8226 cells treated with increasing concentrations of tetrac $(1-50 \mu \mathrm{M})$. Doxorubicin served as a positive control. Representative blots (Fig. 4) indicate a rapid and dose-dependent activation of pATM following 1 and $4 \mathrm{~h}$ of treatment, while at $2 \mathrm{~h}$ or $8 \mathrm{~h}$, this effect was absent or greatly 

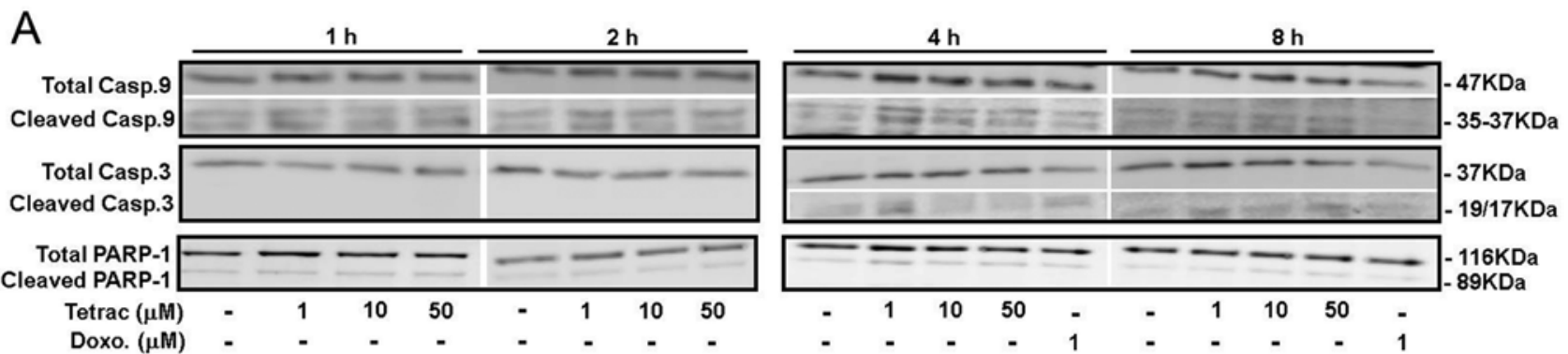

B
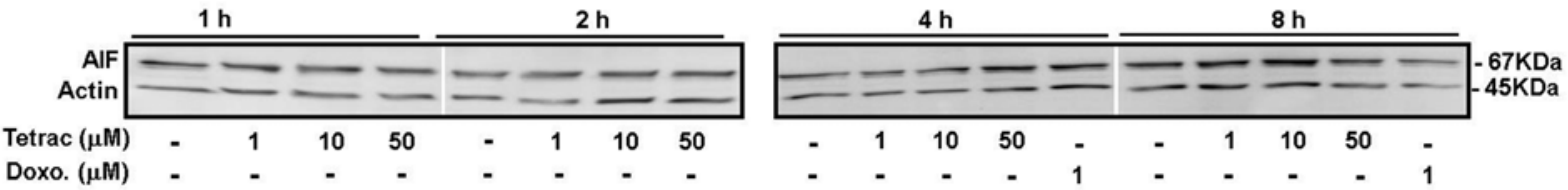

C
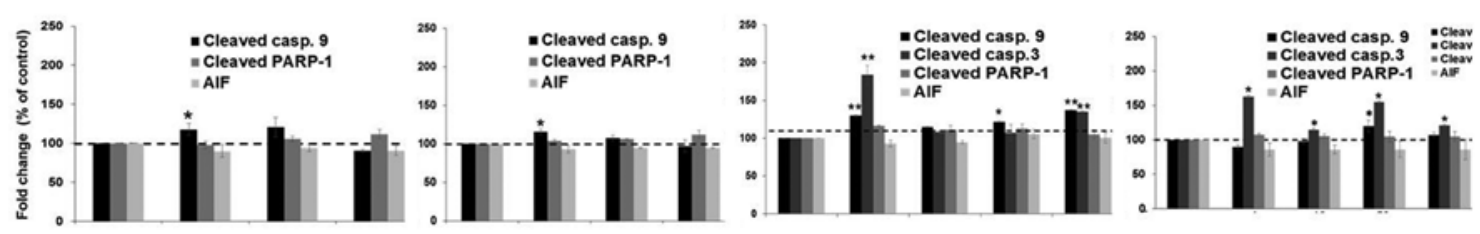

Figure 2

Tetrac activates caspases and PARP-1 cleavage, but not AIF in MM. RPMI-8226 cells were incubated with tetrac (1-50 $\mu \mathrm{M})$ for $1-8 \mathrm{~h}$, total protein was extracted and Western blots were carried out for (A) caspase-9, caspase-3, PARP-1 and (B) AIF. Shown is a representative experiment of two performed (C) Representative quantification of band intensity of the corresponding Western blots is presented as ratio of cleaved target protein over total protein intensity. Values are means \pm S.D. Densitometry is expressed as percentage compared with the vehicle-treated group (considered as $100 \%$, marked by a dashed line). Experiments were repeated twice. ${ }^{*} P \leq 0.05,{ }^{* *} P \leq 0.01$.

attenuated. PARP-1 was induced by all tetrac concentrations after $4 \mathrm{~h}$ of treatment, while no significant effect was observed at the remaining times. Regarding $\gamma \mathrm{H} 2 \mathrm{AX}$, activation was evident after $1 \mathrm{~h}$ of treatment with 10 and $50 \mu \mathrm{M}$ tetrac. At $2 \mathrm{~h}$ of treatment, an increase was observed for 1 and $10 \mu \mathrm{M}$ tetrac concentrations. $\gamma \mathrm{H} 2 \mathrm{AX}$ activation by $1 \mu \mathrm{M}$ tetrac was sustained after $4 \mathrm{~h}$ of treatment. A second peak in $\gamma \mathrm{H} 2 \mathrm{AX}$ phosphorylation was observed after $8 \mathrm{~h}$ of treatment, with 10 and $50 \mu \mathrm{M}$ tetrac concentrations. The calculated results following tetrac incubations are presented in Fig. 4B. Supplementary Figure 5A, B and C depicts results in three additional $\mathrm{MM}$ cell lines, presenting cell-specific time- and dose-dependent response to tetrac.

The effects of tetrac on proliferation, viability, apoptosis and DNA damage repair in MM cells are blocked by RGD

Tetrac-binding site on integrin $\alpha v \beta 3$ is at the thyroid hormone receptor site, near the RGD-recognition site (Cody et al. 2007, Freindorf et al. 2012, Davis et al. 2016). To support integrin involvement, RGD peptide was studied for its effects on tetrac actions. CAG cells were seeded (100,000/96-well plate) and treated in the presence/absence of increasing concentrations of RGD peptide (50, 100 or $200 \mu \mathrm{M})$ and tetrac $(25-100 \mu \mathrm{M})$ overnight $(24 \mathrm{~h}$ of treatment). Representative cell viability experiment indicates that high concentrations of RGD, alone (Fig. 5A, gray line), did not affect cell proliferation, while tetrac, alone (Fig. 5A, black line), reduced cell proliferation in a concentrationdependent manner. This effect was allosterically interfered by increasing RGD concentrations (Fig. 5A, dashed gray lines). No effect was observed with the negative control RGE peptide (Fig. 5B). Comparable viability results were obtained in RPMI-8226 cells (Supplementary Fig. 4D). In addition, cell death (annexin-V/PI) was explored in CAG cells (100,000/96-well plate) treated overnight with high tetrac concentration $(100 \mu \mathrm{M})$ in the presence or absence of RGD $(1-500 \mu \mathrm{M})$. Representative results (Fig. 5C) demonstrate that tetrac reduced the surviving fraction (An-/PI-) by about 50\%, and this effect was hindered by RGD. In accord with the proliferation results, RGD alone had no effect. The increase in apoptotic cell death in response to $100 \mu \mathrm{M}$ tetrac was effectively inhibited by RGD (Fig. 5D). Representative annexin-V/PI results are depicted in Supplementary Fig. 4C.

We next examined whether RGD interfered with the action of tetrac on DNA damage/repair. CAG cells 
- p53-independent $\left(37^{\circ} \mathrm{C}\right) \quad$ " p53-dependent $\left(32^{\circ} \mathrm{C}\right)$
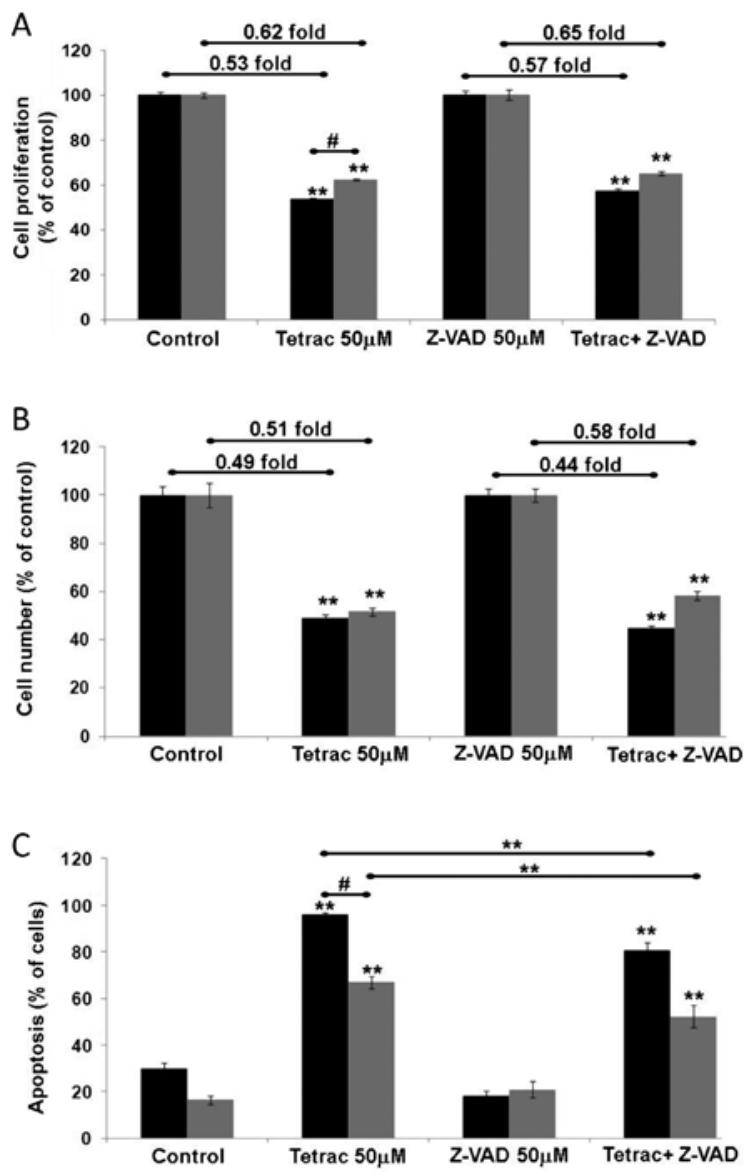
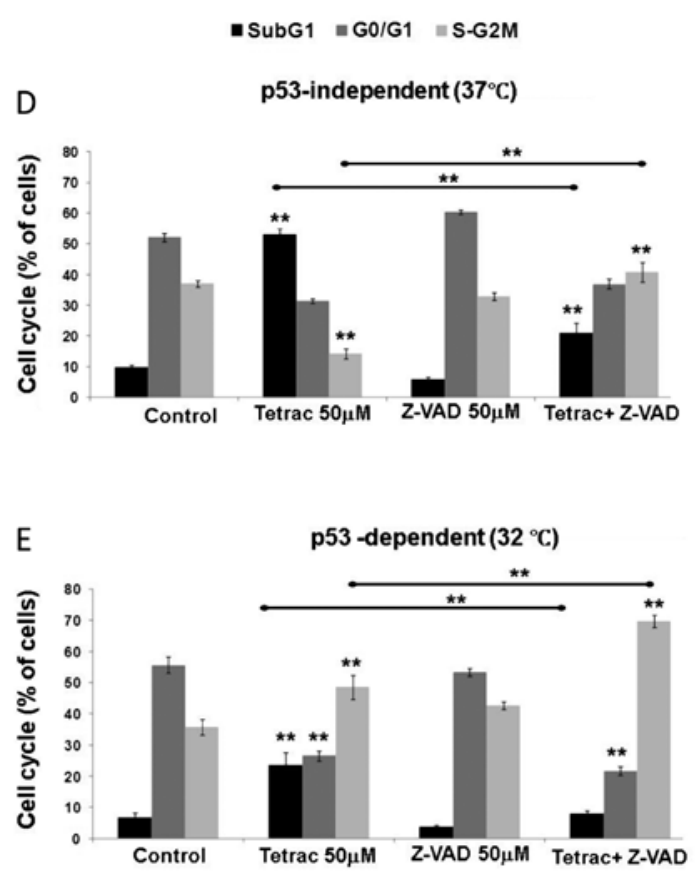

\section{Figure 3}

Involvement of p53 and caspases in action of tetrac on MM cells. Temperature-sensitive RPMI-8226 cells were treated with tetrac \pm Z-VAD-FMK and grown at $32^{\circ} \mathrm{C}$ or $37^{\circ} \mathrm{C}$ and evaluated for (A) cell proliferation (WST-1), (B) cell number (flow-cytometry), (C) apoptosis (Annexin-V/PI) and (D and E) cell cycle, flow-cytometry. Experiments were repeated three times at triplicate. ${ }^{*} P \leq 0.05, * * P \leq 0.01$. Significance between tetrac's effect under $32^{\circ} \mathrm{C}$ and $37^{\circ} \mathrm{C}$ is marked by \#.

were incubated for $24 \mathrm{~h}$ with increasing concentrations $(0.1-100 \mu \mathrm{M})$ of tetrac and RGD, together and alone (Fig. 5E). A representative blot indicates that tetrac significantly increased the level of $\gamma \mathrm{H} 2 \mathrm{AX}$ phosphorylation by 2.8-4.67 fold, while RGD alone had no effect. When $1 \mu \mathrm{M}$ tetrac was combined with RGD (0.1-100 $\mu \mathrm{M})$, the induction in $\gamma \mathrm{H} 2 \mathrm{AX}$ phosphorylation by tetrac was completely prevented (Fig. 5E, gray bars). Thus, the cancer cell-killing actions of tetrac are initiated at the integrin and the RGD recognition site and the tetrac-thyroid hormonebinding site on $\alpha v \beta 3$ are proximal to one another.

Tetrac induces apoptosis in primary BM cells from MM patients

After establishing the cytocidal effects of tetrac in MM cell lines, we examined the effect of the drug on primary
BM cells. Mononuclear cells were isolated from the bone marrow of a myeloma patient (BM \#1). The cells were seeded (100,000 cells/96 wells), treated in triplicates with tetrac $(100 \mathrm{nM}$ or $1 \mu \mathrm{M})$ for $96 \mathrm{~h}$ and tested by annexin-V/PI assay for the presence of early apoptosis (an+/PI-) and for late apoptosis/necrosis (an+/PI+, an-/PI+) by flowcytometry. Samples of the same cells treated with vehicle served as controls. Results demonstrate the induction of apoptosis by tetrac in whole mononuclear cell population (Fig. 6A) and in gated CD-138+ plasma cells (Fig. 6B), in comparison to untreated cells. Following this observation, the experiment was repeated with tetrac for 24-96h in an additional sixteen mononuclear BM samples (BM \#1-17; clinical features are presented in Supplementary Table 1). The results from the entire study cohort (a total of seventeen samples) are presented in Supplementary Table 2. An induction in apoptotic cell death, in response 
A

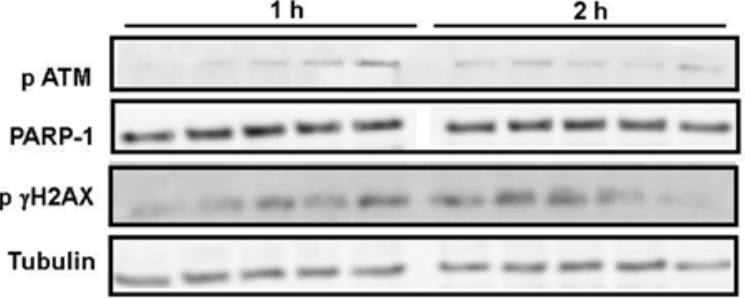

Tetrac $(\mu \mathrm{M}) \quad-\quad 1 \quad 10 \quad 50 \quad-\quad-\quad \begin{array}{lllllll}1 & 1 & 10 & 50 & -\end{array}$

Doxo. $(\mu \mathrm{M})$

B
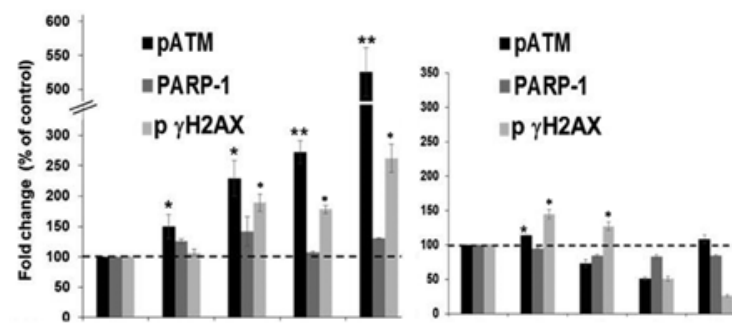
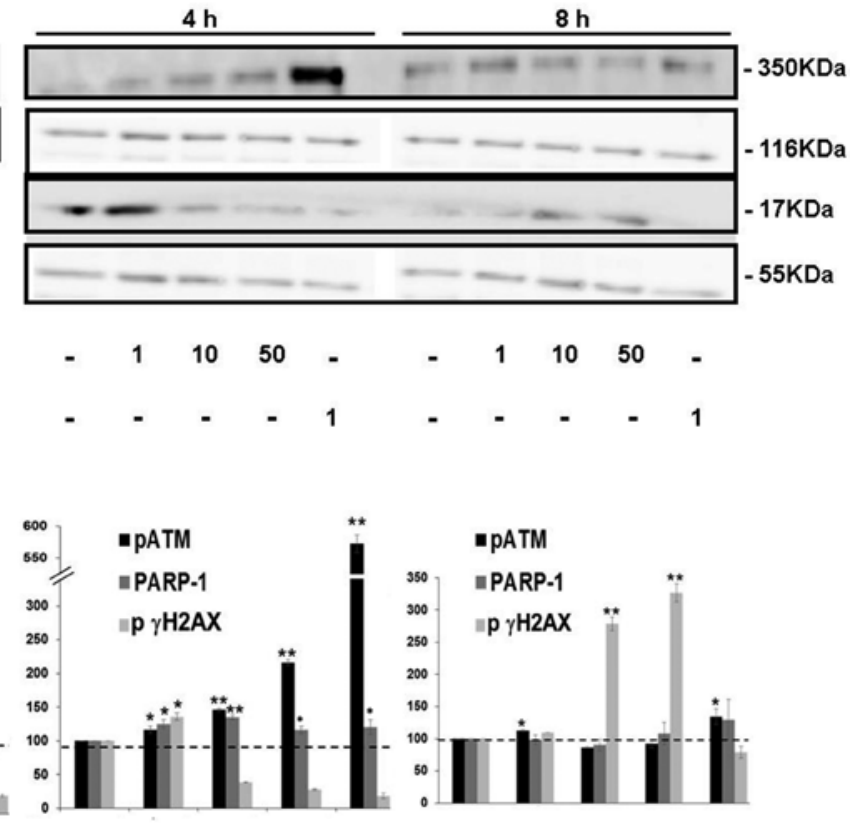

\section{Figure 4}

Tetrac increases DNA damage response markers in MM cells. RPMI-8226 cells were treated with tetrac $(1-50 \mu \mathrm{M})$ for $1-8 \mathrm{~h}$ and were evaluated for pATM, PARP-1 and p $\gamma \mathrm{H} 2 \mathrm{AX}$ level and activation by Western blot. Experiments were repeated twice. Representative quantification of band intensity of the corresponding Western blots is presented as ratio of target protein to tubulin intensity. Values are means \pm s.D. Densitometry is expressed as percentage compared with the vehicle-treated group (considered as $100 \%$, marked by a dashed line). ${ }^{*} P \leq 0.05, * * P \leq 0.01$.

to low tetrac concentrations, was observed in twelve samples in comparison to samples of the same subject treated with vehicle (considered as 100\%), in which the mean rate of basal \% of apoptosis was $15 \pm 5$.

Tetrac sensitizes MM cell lines and primary BM cells to the cytotoxic effect of bortezomib

Bortezomib is the first proteasome inhibitor in clinical use and is a leading treatment agent in MM (Chen et al. 2011). Based on the observation that thyroid hormone can antagonize bortezomib's action (Cohen etal.2015), together with the anticancer activity of tetrac, led us to explore the potential of combined tetrac-bortezomib treatment. RPMI8226 and CAG cells were seeded (100,000/96-well plate), treated overnight with tetrac $(100 \mu \mathrm{M})$ with or without bortezomib $(25 \mathrm{nM})$. Results indicate that bortezomib alone significantly decreased cell proliferation in RPMI8226 cells by $68 \%$ and in CAG cells by $80 \%$; tetrac results were by $60 \%$ and $72 \%$ reductions, respectively (Fig. 7A). The combined treatment lowered the proliferation rate by 80\% in RPMI-8226 and by 90\% in CAG cells. Cell survival (annexin-V/PI, Fig. 7B) was reduced by bortezomib in RPMI-8226 by 35\% and in CAG cells by $70 \%$ while with tetrac by $35 \%$ and $50 \%$, respectively. The combination of the two agents resulted in 55\% and $85 \%$ reductions in cell survival in the two cell lines, respectively. We then evaluated this treatment approach in primary BM mononuclear cells from a representative $\mathrm{MM}$ patient $(\mathrm{BM} \# 1)$ treated with bortezomib ( $25 \mathrm{nM})$ with/without tetrac $(100 \mathrm{nM}-1 \mu \mathrm{M})$. Tetrac sensitized the cells to the cytotoxic effect of bortezomib in the mononuclear cell population (Fig. 7C), and this sensitization was also demonstrated in CD138+ plasma cells (Fig. 7D). A representative annexin-V/PI assay is presented for whole BM cells (Fig. 7E, upper panel) and for CD138+ cells (Fig. 7E, lower panel). The same experiment was conducted on a total of eight additional BM samples, with comparable results obtained in five samples (BM\#3-4, 7, 10 and 11), while in three samples (BM\#2, 8 and 9), no sensitization was achieved (data not shown).

Primary BM cells from MM patients express $\alpha v \beta 3$ integrin

The pleotropic actions of thyroid hormone have been shown to be $\alpha v \beta 3$ integrin mediated in myeloma cell lines (Cohen et al. 2011) and in mononuclear cells from the BM of myeloma patients (Cohen et al. 2015). $\alpha v \beta 3$ integrin expression in myeloma cell lines, composed of $100 \%$ plasma cells (CD138+), is depicted in Supplementary Fig. 6. Comparable expression was shown on sorted plasma cells from BM of myeloma 

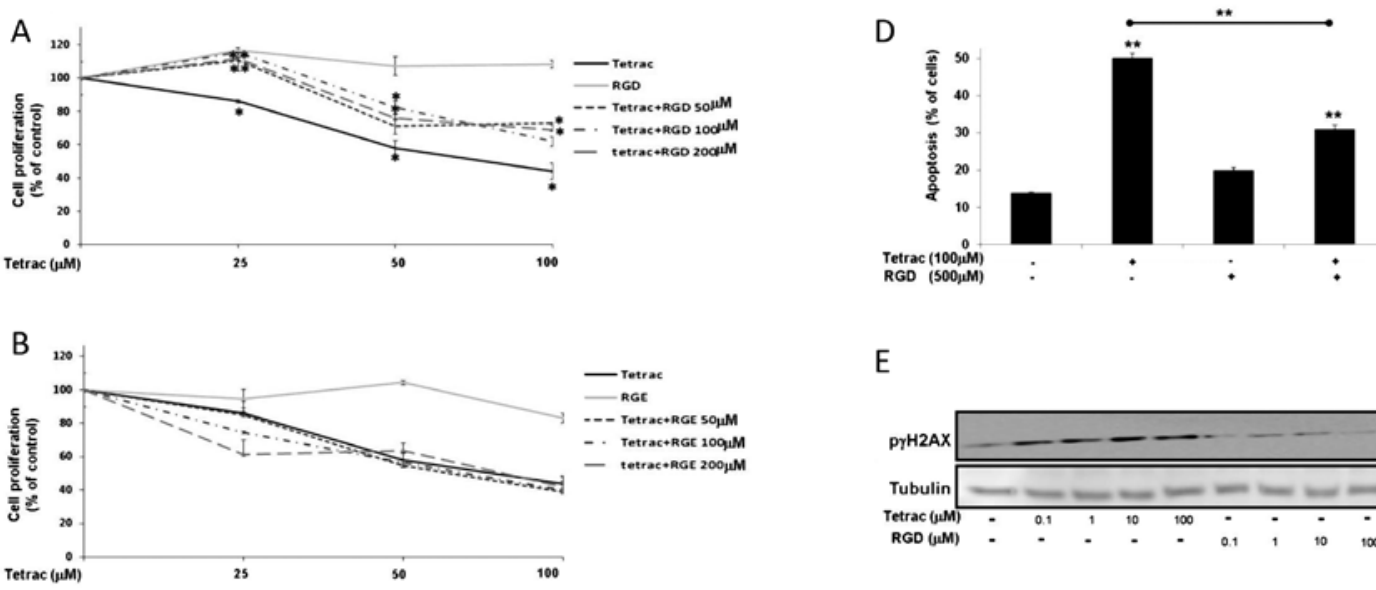

E
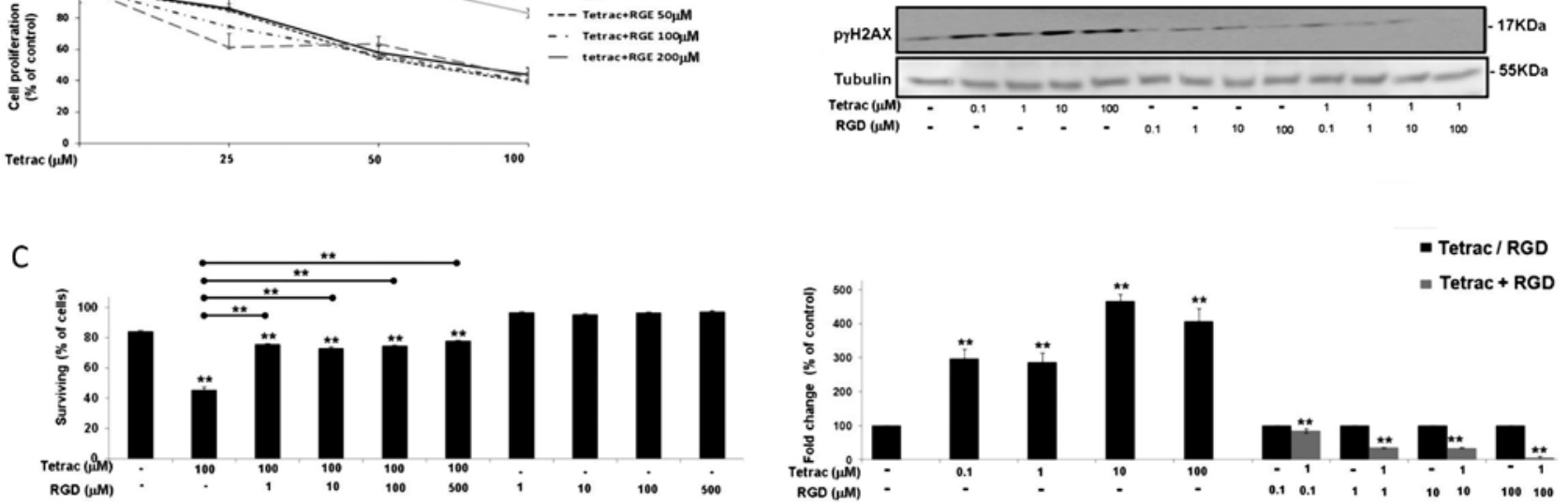

Figure 5

Induction of cell death in MM cells is blocked by RGD. CAG cells were treated for an overnight with various concentrations of tetrac and examined for cell viability (WST-1) in combination with (A) RGD or (B) RGE. Experiments were repeated five times in triplicate. (C) Surviving cells (An-/PI-) and (D) apoptotic cells $(\mathrm{An}+/ \mathrm{PI}-$ and $\mathrm{An}+/ \mathrm{PI}+$ ) were evaluated by flow-cytometry. Experiments were repeated three times in triplicate. (E) p $\mathrm{H} 2 \mathrm{AX}$ protein level and activation (Western blots). The experiment was repeated twice. Representative quantification of band intensity of the corresponding Western blots is presented as ratio of target protein to tubulin intensity. Values are means \pm s.D. Densitometry is expressed as percentage compared with the vehicletreated group (considered as $100 \%$, marked by a dashed line). ${ }^{*} P \leq 0.05, * * P \leq 0.01$.

patients (Ria et al. 2002, Tucci et al. 2009, 2016). Our experimental model utilizes unsorted primary BM plasma cells, allowing study of the malignant clone within its natural surrounding cellular niche. We aimed to establish the integrin expression in this experimental cellular platform.

Mononuclear cells from the $\mathrm{BM}$ of a myeloma patient (BM\#17, relevant clinical data is depicted in Supplementary Table 1) were stained with a FITC-labeled $\alpha v \beta 3$ antibody. Flow-cytometry analysis (Fig. 8A) depicts a high expression of $\alpha v \beta 3$ integrin in $82 \%$ of the cells. We then determined whether the high integrin expression is exclusively contributed by the malignant plasma cell clone. For that, the cells were stained with a plasma cell marker (CD138-APC) and a general mononuclear cells marker (CD45-FITC). Figure 8B depicts the malignant plasma clone (CD138+/CD45-, pink color) and the non-malignant mononuclear cells (CD138-/CD45+, green color). Next, the cells were stained with $\alpha v \beta 3$-FITC antibody and gated for the previously described cell populations. Figure $8 \mathrm{C}$ indicates that the malignant plasma cells (pink color) highly express this integrin, but this expression is also evident in non-malignant mononuclear cells (in green). Forward scatter (FSC) and side scatter (SSC) plot of the various cell populations is presented in Fig. 8D, showing malignant plasma cells (blue), monocytes (yellow), promyelocytes (purple) and lymphocytes (green). The relative $\alpha v \beta 3$ integrin expression in the different cell populations is shown in Fig. 8E. The same gating strategy was evaluated in a total of 25 MM BM samples (BM\#5-6 and 17-39; relevant clinical data is depicted in Supplementary Table 1). In the majority of BM samples examined (19/25 samples, Supplementary Fig. 7A), positive integrin expression was documented, while the remaining samples were negative (a representative example is shown in Supplementary Fig. 7B). An additional normal BM sample was completely negative for the integrin expression (Control \#1, Supplementary Fig. 7A). Although the highest integrin expression was frequently exhibited by the malignant plasma clone, in some cases, it was more pronounced in other mononuclear cells 

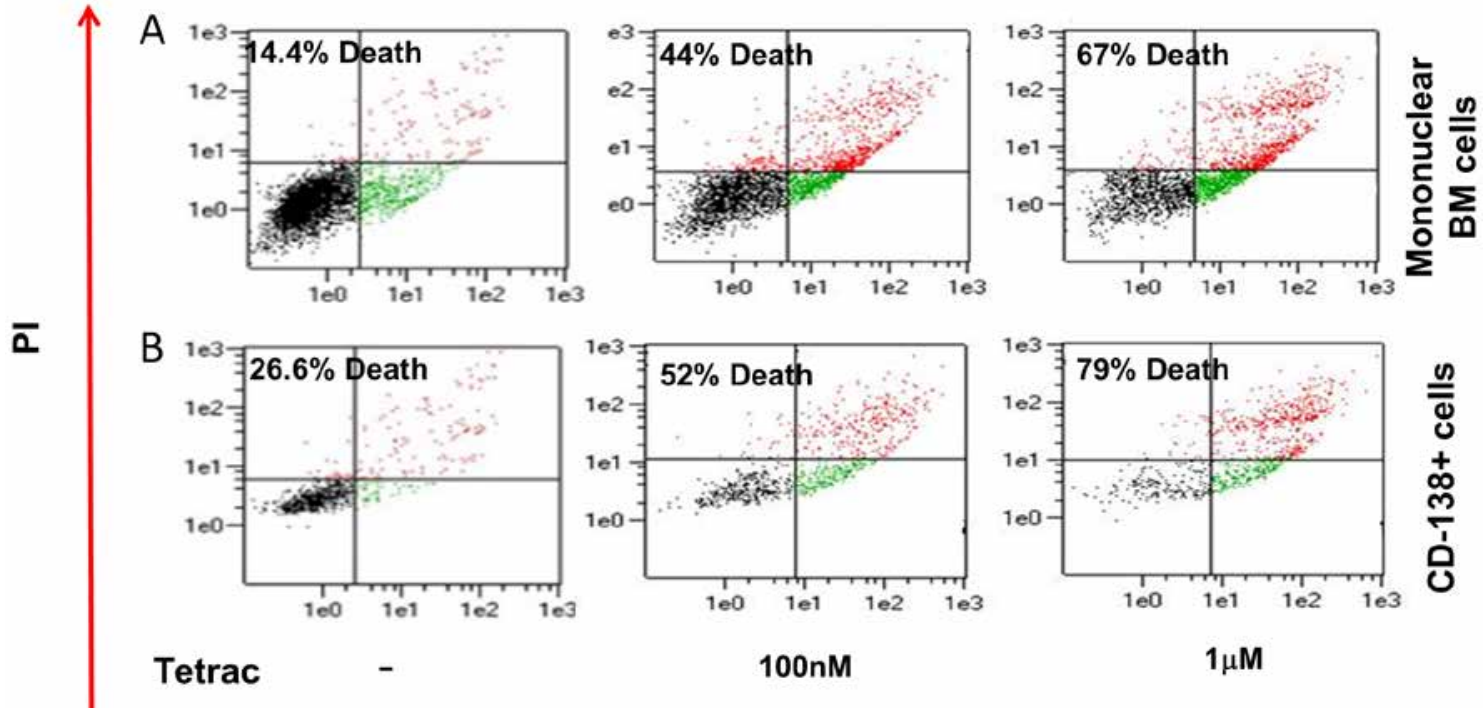

Annexin-FITC

Figure 6

Tetrac induces apoptosis in primary BM cells from MM patients. (A) Mononuclear cells from a MM BM sample (BM\#1) were separated by Ficoll gradient, treated in triplicates with tetrac $(100 \mathrm{nM}-1 \mu \mathrm{M})$ for $96 \mathrm{~h}$ and then analyzed for cell death (Annexin-V/PI, flow-cytometry). (A) Representative results for whole BM cells and (B) CD138+ cells. Samples of the same subject treated with vehicle served as controls. A full color version of this figure is available at https://doi.org/10.1530/ERC-17-0246.

(a representative example is shown in Supplementary Fig. 7C). Taken together, these collective results indicate that $\alpha v \beta 3$ integrin is expressed not only on the malignant myeloma clone, but also on the surrounding BM microenvironment cells.

\section{Discussion}

Tetrac is a naturally occurring deaminated analog of $\mathrm{T}_{4}$ that binds the $\alpha v \beta 3$ integrin in two orientations and competitively displace both $\mathrm{T}_{3}$ and $\mathrm{T}_{4}$, eliminating their non-genomic activities (Bergh et al. 2005, Davis et al. 2011, Freindorf et al. 2012). Tetrac possesses low hormone activity because of shortening of the side chain on the inner ring (removal of a carbon and amine), resulting in the conversion of propionic acid (thyroid hormone) to acetic acid (tetrac/ triac). This transforms the compounds from thyroid agonist at the thyroid hormone receptors, to antagonist (Davis et al. 2011). These antagonistic effects were extensively studied in vitro and in animal cancer models (reviewed in Davis et al. 2016), but never examined in MM. In the current work, we have focused on blocking the thyroid hormone- $\alpha v \beta 3$ axis using tetrac in $\alpha v \beta 3$ integrin expressing MM cells. By a number of complementary methods in several myeloma cell lines, tetrac produced anti-proliferative effects that were not affected by caspase inhibition and pro-apoptotic effects that were caspase-9 and caspase-3-dependent. No involvement of AIF, a caspase-independent apoptosis marker, was recognized. The peak antitumor action of unmodified tetrac nongenomically initiated at the thyroid hormone-tetrac receptor site on integrin $\alpha \mathrm{v} \beta 3$ is at $10^{-7}-10^{-6} \mathrm{M}$ (Lin et al. 2011). The antagonistic effects were observed by tetrac in the myeloma cell models mainly at high molar concentrations. However, no toxicity was detected in mice treated with up to $60 \mathrm{mg} / \mathrm{kg}$ tetrac (equivalent to $250 \mu \mathrm{M}$ tetrac concentration) (Rebbaa et al. 2008). At the indicated concentrations, tetrac was well tolerated, and no significant toxicity was noticed, including unchanged animal weights over the course of the study. To note, the effects produced by tetrac were not always concentration dependent. Similar non-linear integrinligand association with other ligands (activators/inhibitors) was reported (Legler et al. 2001, Li \& Springer 2017). This may be attributed to the fact that integrins are altered following binding of ligands (Campbell \& Humphries 2011). Such changes in the integrin configuration may alter the accessibility of ligands at different concentrations to various receptor sites on the integrin. Tetrac binding may therefore alter the integrin conformation, producing a non-linear effect.

To study the role of $\mathrm{p53}$, a central regulator of apoptosis, in tetrac's pro-apoptotic action, temperaturesensitive RPMI-8226 cells that express mutant p53 

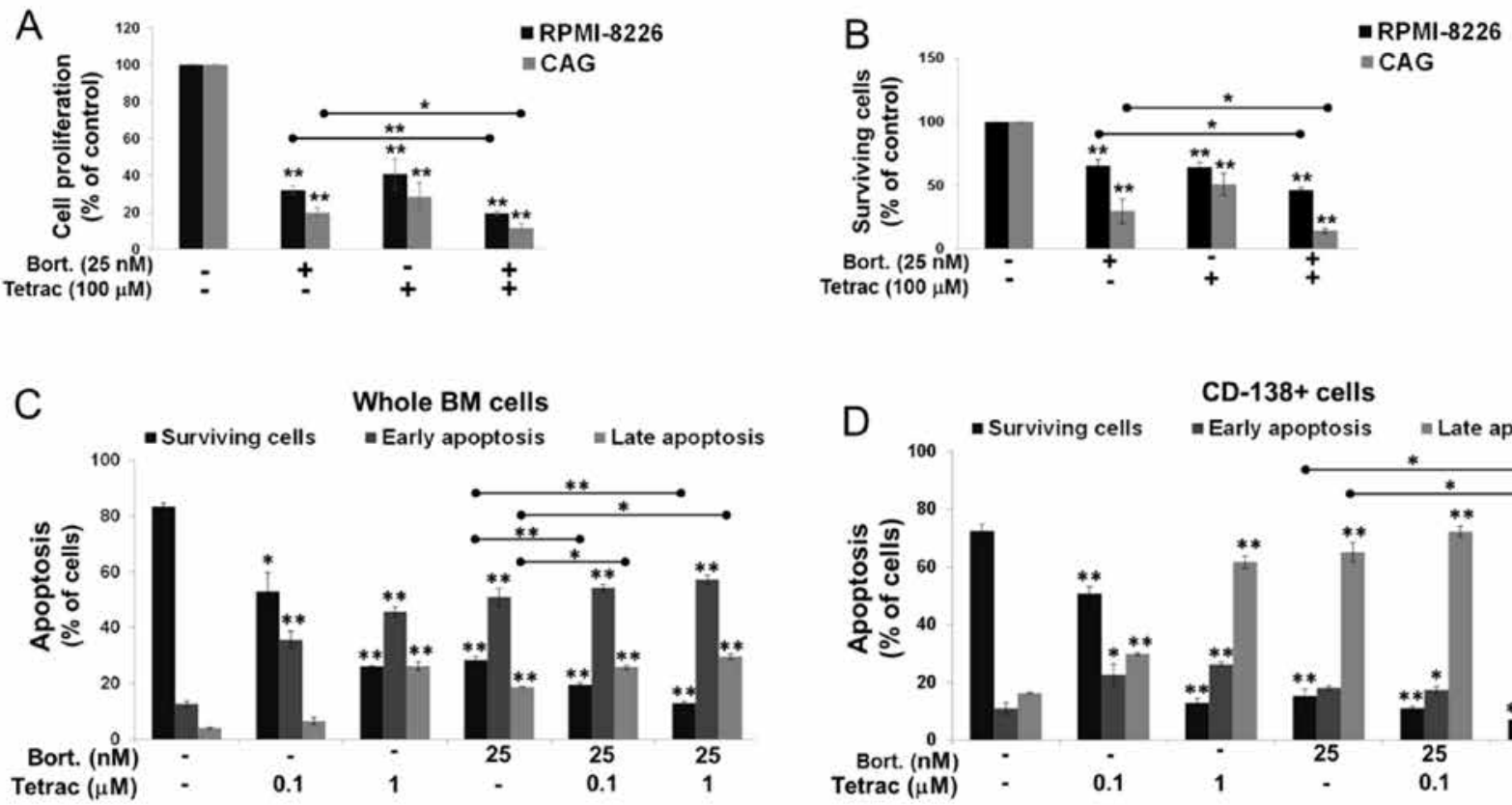

\section{Whole BM cells}

- Early apoptosis =Late apoptosis

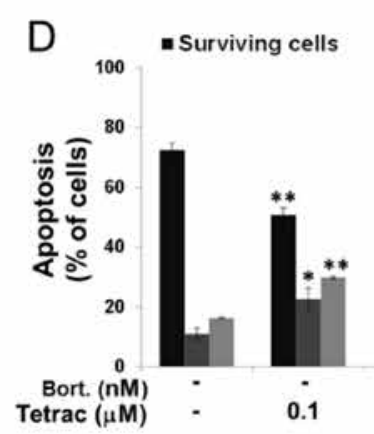

CD-138+ cells
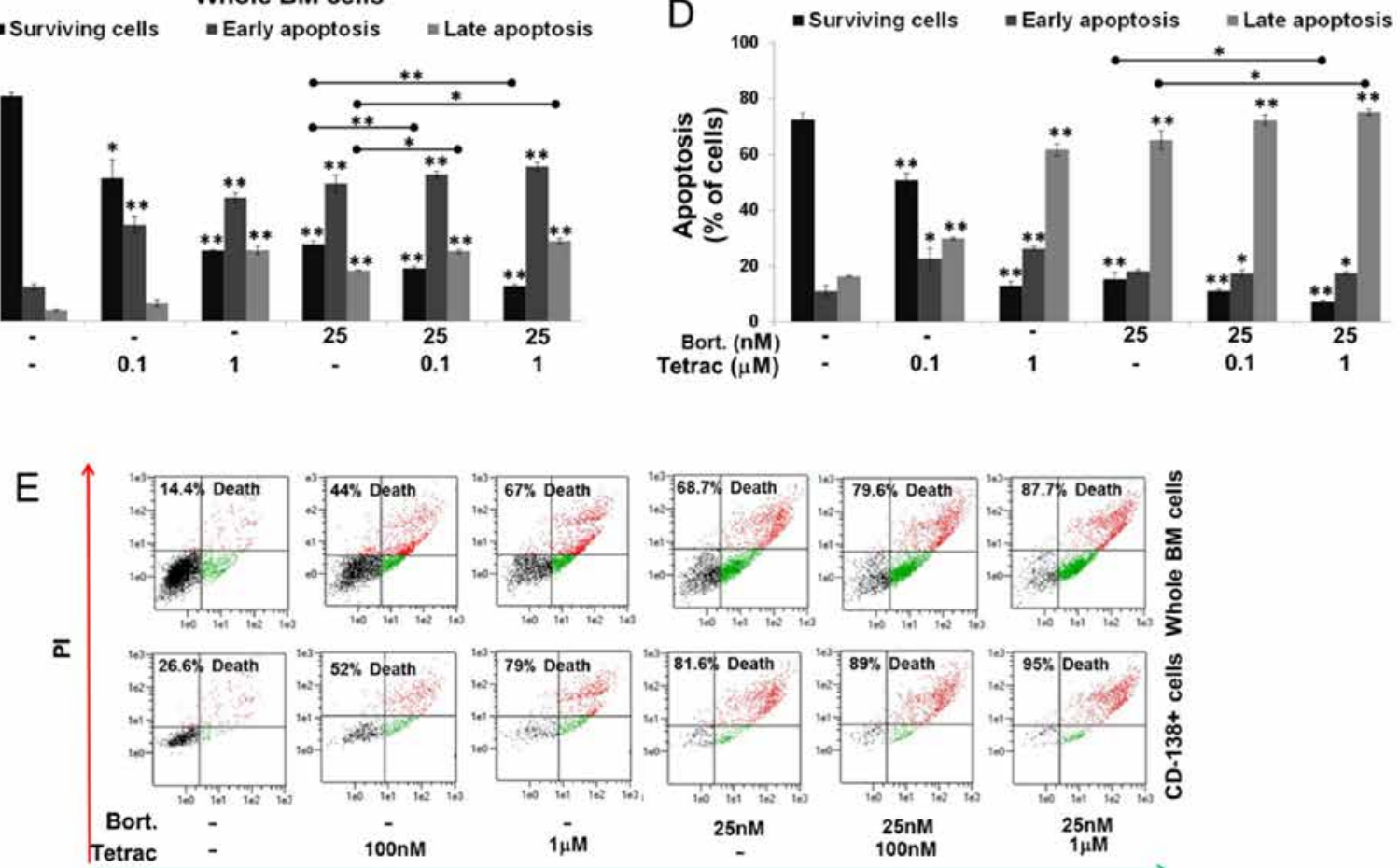

Annexin-FITC

Figure 7

Tetrac sensitizes MM cell lines and primary cells to bortezomib. RPMI-8226 and CAG cells were treated with bortezomib ( $25 \mathrm{nM}$ ) with/without tetrac $(100 \mu \mathrm{M})$ and were analyzed for (A) cell proliferation (WST-1, ELISA) and (B) survival (annexin-V/PI, flow-cytometry). Experiments were repeated at least 3 times, in triplicate. Primary BM cells from MM patients were treated with bortezomib $(25 \mathrm{nM})$ with/without tetrac $(100 \mathrm{nM}-1 \mu \mathrm{M})$ and were analyzed for (C and D) apoptosis (annexin-V/PI, flow-cytometry). (E) Representative annexin/PI results from a BM sample (BM\#1) in whole BM cells (upper panel) and gated CD138+ plasma cells (lower panel). ${ }^{*} P \leq 0.05,{ }^{*} P \leq 0.01$. A full color version of this figure is available at https://doi.org/10.1530/ERC-17-0246.

(E285K) at $37^{\circ} \mathrm{C}$ and wild type at $32^{\circ} \mathrm{C}$, were used (Teoh et al. 2000, Hu et al. 2015). In the absence of active p53, tetrac induced caspase-dependent apoptosis, while in the presence of wild-type p53, the induction of caspasedependent cell death was accompanied by cell cycle arrest that correlates with the well-established role of p53 as a cell cycle regulator (Giono \& Manfredi 2006).

Key proteins that coordinate the recognition of DNA damage, ATM, PARP-1 and histone $\gamma \mathrm{H} 2 \mathrm{AX}$ were rapidly induced by tetrac. In cell-free assays (unpublished data), we have demonstrated that tetrac does not directly bind to DNA and induce breaks, but rather inhibits DNA repair mechanisms. This observation is supported by experiments in which this drug did not induce direct DNA damage but led to a potent reduction in repair mechanisms (Hercbergs et al. 2011, Leith et al. 2017). Additional experiments, such as ChIPSeq, should be performed to reveal the mechanism by which tetrac inhibits DNA repair. To note, unmodified tetrac may also interfere with the classical hormones action at other levels, such as the cellular entry of $\mathrm{T}_{4}$ and other non-genomic effects that do not involve $\alpha v \beta 3$ signaling. Therefore, additional intracellular effects by unmodified tetrac cannot be ruled out. 
A

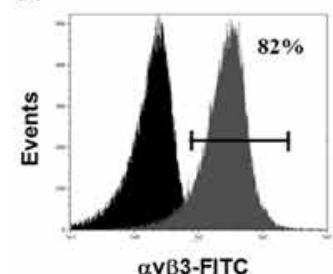

B

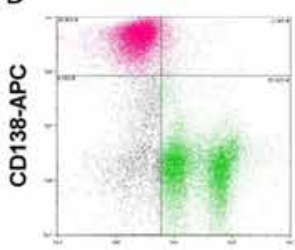

CD45-FITC
C

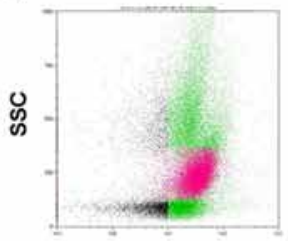

$\alpha v \beta 3-F I T C$
D

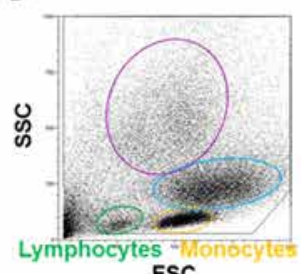

$E$

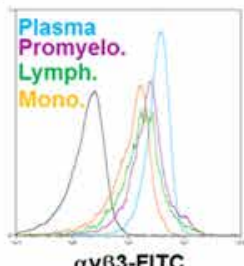

$\alpha v \beta 3-F I T C$

Figure 8

Primary bone marrow cells from MM patients highly express $\alpha \mathrm{v} \beta 3$ integrin. Flow-cytometry analysis of cells incubated with (A) $\alpha \mathrm{v} \beta 3$ antibody and (B) CD138-APC and CD45-FITC antibodies. Malignant plasma cell clone is depicted in pink; mononuclear cells in green. (C) Analysis of expression of integrin in CD138+ (pink) vs CD138-cells (green). (D) Forward scatter (FSC) and side scatter (SSC) plot of the various cell populations: plasma cells (blue), promyelocytes (purple), monocytes (yellow) and lymphocytes (green). (E) Relative $\alpha v \beta 3$ expression in the various cell populations. Isotype control is depicted in black.

Three-dimensional crystallographic modeling of the $\alpha v \beta 3$ integrin confirmed that tetrac-binding site, similar to that of the thyroid hormones, is located near the RGDrecognition site (Cody et al. 2007, Freindorf et al. 2012, Davis et al. 2016). Our results show that various tetracinitiated effects were attenuated in the presence of RGD. Moreover, at equimolar concentrations, it appeared that tetrac was far more potent than RGD, which had no effect whatsoever, even at high micromolar concentrations. These results appear to be consistent with preclinical and clinical experience with RGD antagonists which report that high millimolar concentrations are required to produce an inhibitory effect in cancer (Weis et al. 2009).

Experiments performed on primary BM cells from MM patients often involve the enrichment of the samples with CD138+ plasma cells. However, this approach overlooks other mononuclear cells that are present in the BM. Given the recently acknowledged importance of the microenvironment in supporting MM (Rossi et al. 2013), there might be an advantage in studying the malignant clone within its natural surrounding niche. Such studies on heterogeneous cell populations in the myeloma BM have been reported (Lichtenstein et al. 1989, Liu et al. 2005, Noll et al. 2014, Chen et al. 2017, Gao et al. 2017). In this work, tetrac at low concentrations induced apoptosis in primary $\mathrm{BM}$ mononuclear $\mathrm{MM}$ cells at various disease stages. This apoptosis was evident in whole BM mononuclear cells and more profoundly in the plasma cell clone. Although no correlation between the response to tetrac and disease stage was documented, this should be examined in a larger scale study. Of note, in myeloma cell lines, the concentrations of tetrac needed to produce an apoptotic effect were generally higher. This may suggest that the mononuclear cellular milieu susceptible to tetrac indirectly assists in MM cell death.
We have reported that thyroid hormone antagonizes the cytotoxic effect of bortezomib (Cohen et al. 2015). Given that tetrac is a selective inhibitor of the $T_{3} / T_{4}-\alpha v \beta 3$ axis, we hypothesized that there would be an advantage in combining tetrac with bortezomib. Our results provided support for a sensitizing effect for most actions in the combined treatment. Tetrac has been shown before to increase the sensitivity of resistant cancer cells to chemotherapy (Rebbaa et al. 2008, Davis et al. 2011, 2014), via the plasma membrane multi-drug resistance (MDR) pumps.

Finally, the expression of $\alpha v \beta 3$ integrin in whole BM mononuclear cells was revealed not only on the malignant plasma clone, as previously reported (Ria et al. 2002, Tucci et al. 2009), but also on heterogeneous cell populations within the BM (monocytes, lymphocytes and promyelocytes). The expression of $\alpha v \beta 3$ on peripheral blood monocytes and granulocytes has recently been reported (Shojaei et al. 2012). To the best of our knowledge, our results are the first to indicate $\alpha v \beta 3$ abundance on monocytes, granulocyte precursors (promyelocytes) and lymphocytes in the MM BM. These results point out that the thyroid hormone- $\alpha \mathrm{v} \beta 3$ axis may be relevant not only to the malignant clone, but also to the surrounding BM mononuclear cells. Such an assumption was recently supported by another study showing the relevance of the thyroid hormone- $\alpha v \beta 3$ axis to the crosstalk between the BM microenvironment and other malignant cells (Schmohl et al. 2015, Davis et al. 2016). This further suggests that it may be important to study primary MM cells in the context of their stromal cell milieu.

In conclusion, tetrac generated anti-proliferative and pro-apoptotic responses and increased the sensitivity to combined tetrac-bortezomib treatment in MM cells. This, together with our observation of $\alpha v \beta 3$ integrin 
expression in primary $\mathrm{MM}$ and stromal cells, highlights the relevance of this integrin in this disease and suggests that pharmacologic inhibition of the thyroid hormoneintegrin $\alpha v \beta 3$ pathway may serve as a potential approach to disease management.

\section{Supplementary data}

This is linked to the online version of the paper at https://doi.org/10.1530/ ERC-17-0246.

\section{Declaration of interest}

Co-author P J D is stockholder and officer in a company developing modified forms of tetrac as anticancer agents. The other authors declare that there is no conflict of interest that could be perceived as prejudicing the impartiality of the research reported.

\section{Funding}

This research did not receive any specific grant from any funding agency in the public, commercial or not-for-profit sector.

\section{Author contribution statement}

K C designed, preformed, analyzed and interpreted the experimental data. U A and M E assisted in the selection of patients included in the study and the collection of the BM samples. O A F designed, analyzed and interpreted the experimental data. K C, P J D, A H, M E and O A F wrote the manuscript. All authors read and approved the final manuscript.

\section{Acknowledgments}

The work of Keren Cohen was done in partial fulfillment of the requirements for a PhD degree from the Sackler Faculty of Medicine, Tel Aviv University, Israel.

\section{References}

Aghajanova L, Stavreus-Evers A, Lindeberg M, Landgren BM, Sparre LS \& Hovatta O 2011 Thyroid-stimulating hormone receptor and thyroid hormone receptors are involved in human endometrial physiology. Fertility and Sterility 95 230-237. (https://doi.org/10.1016/j. fertnstert.2010.06.079)

Baldazzi V, Tassi R, Lapini A, Santomaggio C, Carini M \& Mazzanti R 2010 The impact of sunitinib-induced hypothyroidism on progression-free survival of metastatic renal cancer patients: a prospective single-center study. Urologic Oncology 30 704-710. (https://doi.org/10.1016/j.urolonc.2010.07.015)

Bergh JJ, Lin HY, Lansing L, Mohamed SN, Davis FB, Mousa S \& Davis PJ 2005 Integrin alphaVbeta3 contains a cell surface receptor site for thyroid hormone that is linked to activation of mitogen-activated protein kinase and induction of angiogenesis. Endocrinology 146 2864-2871. (https://doi.org/10.1210/en.2005-0102)

Campbell ID \& Humphries MJ 2011 Integrin structure, activation, and interactions. Cold Spring Harbor Perspectives in Biology 3 pii: a004994. (https://doi.org/10.1101/cshperspect.a004994)

Chen D, Frezza M, Schmitt S, Kanwar J \& Dou QP 2011 Bortezomib as the first proteasome inhibitor anticancer drug: current status and future perspectives. Current Cancer Drug Targets 11 239-253. (https:// doi.org/10.2174/156800911794519752)

Chen H, Li M, Sanchez E, Wang CS, Lee T, Soof CM, Casas CE, Cao J, Xie C, Udd KA, et al. 2017 Combined TRAF6 targeting and proteasome blockade has anti-tumor and anti-bone resorptive effects. Molecular Cancer Research 15 598-609.

Cody V, Davis PJ \& Davis FB 2007 Molecular modeling of the thyroid hormone interactions with alpha v beta 3 integrin. Steroids $\mathbf{7 2}$ 165-170. (https://doi.org/10.1016/j.steroids.2006.11.008)

Cohen K, Ellis M, Khoury S, Davis PJ, Hercbergs A \& Ashur-Fabian O 2011 Thyroid hormone is a MAPK-dependent growth factor for human myeloma cells acting via alphavbeta3 integrin. Molecular Cancer Research 9 1385-1394. (https://doi.org/10.1158/1541-7786.MCR-11-0187)

Cohen K, Ellis M, Shinderman E, Khoury S, Davis PJ, Hercbergs A \& Ashur-Fabian O 2015 Relevance of the thyroid hormonesalphavbeta3 pathway in primary myeloma bone marrow cells and to bortezomib action. Leukemia and Lymphoma 56 1107-1114. (https:// doi.org/10.3109/10428194.2014.947612)

Cristofanilli M, Yamamura Y, Kau S, Bevers T, Strom S, Patangan M, Hsu L, Krishnamurthy S, Theriault R \& Hortobagyi G 2005 Thyroid hormone and breast carcinoma. Primary hypothyroidism is associated with a reduced incidence of primary breast carcinoma. Cancer 103 1122-1128. (https://doi.org/10.1002/cncr.20881)

Dalamaga M, Karmaniolas K, Papadavid E, Pelecanos N \& Migdalis I 2008 Association of thyroid disease and thyroid autoimmunity with multiple MM risk: a case-control study. Leukemia and Lymphoma 49 1545-1552. (https://doi.org/10.1080/10428190802165946)

Davis PJ, Davis FB, Mousa SA, Luidens MK \& Lin HY 2011 Membrane receptor for thyroid hormone: physiologic and pharmacologic implications. Annual Review of Pharmacology and Toxicology $\mathbf{5 1}$ 99-115. (https://doi.org/10.1146/annurev-pharmtox-010510-100512)

Davis PJ, Lin HY, Sudha T, Yalcin M, Tang HY, Hercbergs A, Leith JT, Luidens MK, Ashur-Fabian O, Incerpi S, et al. 2014 Nanotetrac targets integrin alphavbeta3 on tumor cells to disorder cell defense pathways and block angiogenesis. OncoTargets and Therapy 7 1619-1624. (https://doi.org/10.2147/OTT.S67393)

Davis PJ, Goglia F \& Leonard JL 2016 Nongenomic actions of thyroid hormone. Nature Reviews Endocrinology 12 111-121.

Desgrosellier JS \& Cheresh DA 2010 Integrins in cancer: biological implications and therapeutic opportunities. Nature Reviews Cancer 10 9-22. (https://doi.org/10.1038/nrc2748)

Freindorf M, Furlani TR, Kong J, Cody V, Davis FB \& Davis PJ 2012 Combined $\mathrm{QM} / \mathrm{MM}$ study of thyroid and steroid hormone analogue interactions with alphavbeta3 integrin. Journal of Biomedicine and Biotechnology 2012959057.

Gao D, Xiao Z, Li HP, Han DH \& Zhang YP 2017 LncRNA MALAT-1 elevates HMGB1 to promote autophagy resulting in inhibition of tumor cell apoptosis in multiple myeloma. Journal of Cellular Biochemistry 118 3341-3348.

Giono LE \& Manfredi JJ 2006 The p53 tumor suppressor participates in multiple cell cycle checkpoints. Journal of Cellular Physiology 209 13-20. (https://doi.org/10.1002/jcp.20689)

Glinskii AB, Glinsky GV, Lin HY, Tang HY, Sun M, Davis FB, Luidens MK, Mousa SA, Hercbergs AH \& Davis PJ 2009 Modification of survival pathway gene expression in human breast cancer cells by tetraiodothyroacetic acid (tetrac). Cell Cycle 8 3554-3562.

Hellevik A, Asvold B, Bjøro T, Romundstad P, Nilsen T \& Vatten L 2009 Thyroid function and cancer risk: a prospective population study. Cancer Epidemiology, Biomarkers and Prevention 18 570-574. (https:// doi.org/10.1158/1055-9965.EPI-08-0911)

Hercbergs AH, Ashur-Fabian O \& Garfield D 2010 Thyroid hormones and cancer: clinical studies of hypothyroidism in oncology. Current Opinion in Endocrinology, Diabetes and Obesity 17 432-436. (https:// doi.org/10.1097/MED.0b013e32833d9710)

Hercbergs AH, Lin HY, Davis FB, Davis PJ \& Leith JT 2011 Radiosensitization and production of DNA double-strand breaks in 
U87MG brain tumor cells induced by tetraiodothyroacetic acid (tetrac). Cell Cycle 10 352-357. (https://doi.org/10.4161/ cc.10.2.14641)

Hu Y, Song W, Cirstea D, Lu D, Munshi NC \& Anderson KC 2015 CSNK1alpha1 mediates malignant plasma cell survival. Leukemia 29 474-482. (https://doi.org/10.1038/leu.2014.202)

Illouz F, Laboureau-Soares S \& Dubois S 2009 Tyrosine kinase inhibitors and modifications of thyroid function. European Journal of Endocrinology 160 331-336. (https://doi.org/10.1530/EJE-08-0648)

Legler DF, Wiedle G, Ross FP \& Imhof BA 2001 Superactivation of integrin alphavbeta3 by low antagonist concentrations. Journal of Cell Science 114 1545-1553.

Leith JT, Davis PJ, Mousa SA \& Hercbergs AA 2017 In vitro effects of tetraiodothyroacetic acid combined with X-irradiation on basal cell carcinoma cells. Cell Cycle 16 367-373. (https://doi.org/10.1080/1538 4101.2016.1269044)

Li J \& Springer TA 2017 Integrin extension enables ultrasensitive regulation by cytoskeletal force. PNAS 114 4685-4690. (https://doi. org/10.1073/pnas.1704171114)

Lichtenstein A, Berenson J, Norman D, Chang MP \& Carlile A 1989 Production of cytokines by bone marrow cells obtained from patients with multiple myeloma. Blood 74 1266-1273.

Lin HY, Landersdorfer CB, London D, Meng R, Lim CU, Lin C, Lin S, Tang HY, Brown D, Van Scoy B, et al. 2011 Pharmacodynamic modeling of anti-cancer activity of tetraiodothyroacetic acid in a perfused cell culture system. PLOS Computational Biology 7 e1001073. (https://doi.org/10.1371/journal.pcbi.1001073)

Liu S, Ishikawa H, Li FJ, Ma Z, Otsuyama K, Asaoku H, Abroun S, Zheng X, Tsuyama N, Obata M, et al. 2005 Dehydroepiandrosterone can inhibit the proliferation of myeloma cells and the interleukin-6 production of bone marrow mononuclear cells from patients with myeloma. Cancer Research 65 2269-2276. (https://doi. org/10.1158/0008-5472.CAN-04-3079)

Mousa SA, Bergh JJ, Dier E, Rebbaa A, O'Connor LJ, Yalcin M, Aljada A, Dyskin E, Davis FB, Lin HY, et al. 2008 Tetraiodothyroacetic acid, a small molecule integrin ligand, blocks angiogenesis induced by vascular endothelial growth factor and basic fibroblast growth factor. Angiogenesis 11 183-190. (https://doi.org/10.1007/s10456007-9088-7)

Mousa SA, Yalcin M, Bharali DJ, Meng R, Tang HY, Lin HY, Davis FB \& Davis PJ 2012 Tetraiodothyroacetic acid and its nanoformulation inhibit thyroid hormone stimulation of non-small cell lung cancer cells in vitro and its growth in xenografts. Lung Cancer 76 39-45. (https://doi.org/10.1016/j.lungcan.2011.10.003)

Nelson M, Hercbergs A, Rybicki L \& Strome M 2006 Association between development of hypothyroidism and improved survival in patients with head and neck cance. Archives of Otolaryngology: Head and Neck Surgery 132 1041-1046. (https://doi.org/10.1001/ archotol.132.10.1041)

Ness R, Grisso J, Cottreau C, Klapper J, Vergona R, Wheeler J, Morgan M \& Schlesselman J 2000 Factors related to inflammation of the ovarian epithelium and risk of ovarian cancer. Epidemiology $\mathbf{1 1}$ 111-117. (https://doi.org/10.1097/00001648-200003000-00006)

Noll JE, Williams SA, Tong CM, Wang H, Quach JM, Purton LE, Pilkington K, To LB, Evdokiou A, Gronthos S, et al. 2014 Myeloma plasma cells alter the bone marrow microenvironment by stimulating the proliferation of mesenchymal stromal cells. Haematologica 99 163-171. (https://doi.org/10.3324/ haematol.2013.090977)
Rebbaa A, Chu F, Davis FB, Davis PJ \& Mousa SA 2008 Novel function of the thyroid hormone analog tetraiodothyroacetic acid: a cancer chemosensitizing and anti-cancer agent. Angiogenesis 11 269-276. (https://doi.org/10.1007/s10456-008-9110-8)

Ria R, Vacca A, Ribatti D, Di Raimondo F, Merchionne F \& Dammacco F 2002 Alpha(v)beta(3) integrin engagement enhances cell invasiveness in human multiple MM. Haematologica 87 836-845.

Rossi M, Botta C, Correale P, Tassone P \& Tagliaferri P 2013 Immunologic microenvironment and personalized treatment in multiple myeloma. Expert Opinion on Biological Therapy 13 (Supplement 1) S83-S93. (https://doi.org/10.1517/14712598.2013.799130)

Schmidinger M, Vogl U, Bojic M, Lamm W, Heinzl H, Haitel A, Clodi M, Kramer G \& Zielinski C 2010 Hypothyroidism in patients with renal cell carcinoma. Blessing or curse? Cancer 117 534-544.

Schmohl KA, Muller AM, Wechselberger A, Ruhland S, Salb N, Schwenk N, Heuer H, Carlsen J, Goke B, Nelson PJ, et al. 2015 Thyroid hormones and tetrac: new regulators of tumour stroma formation via integrin alphavbeta3. Endocrine-Related Cancer 22 941-952. (https://doi.org/10.1530/ERC-15-0245)

Shinderman-Maman E, Cohen K, Weingarten C, Nabriski D, Twito O, Baraf L, Hercbergs A, Davis PJ, Werner H, Ellis M, et al. 2016 The thyroid hormone-alphavbeta3 integrin axis in ovarian cancer: regulation of gene transcription and MAPK-dependent proliferation. Oncogene 35 1977-1987. (https://doi.org/10.1038/ onc.2015.262)

Shojaei F, Scott N, Kang X, Lappin PB, Fitzgerald AA, Karlicek S, Simmons BH, Wu A, Lee JH, Bergqvist S, et al. 2012 Osteopontin induces growth of metastatic tumors in a preclinical model of nonsmall lung cancer. Journal of Experimental and Clinical Cancer Research 31 26. (https://doi.org/10.1186/1756-9966-31-26)

Teoh G, Tai YT, Urashima M, Shirahama S, Matsuzaki M, Chauhan D, Treon SP, Raje N, Hideshima T, Shima Y, et al. 2000 CD40 activation mediates p53-dependent cell cycle regulation in human multiple myeloma cell lines. Blood 95 1039-1046.

Tucci M, De Palma R, Lombardi L, Rodolico G, Berrino L, Dammacco F \& Silvestris F 2009 beta(3) Integrin subunit mediates the bone-resorbing function exerted by cultured myeloma plasma cells. Cancer Research 69 6738-6746. (https://doi.org/10.1158/0008-5472.CAN-09-0949)

Tucci M, Stucci S, Felici C, Cafforio P, Resta L, Rossi R \& Silvestris F 2016 Cilengitide restrains the osteoclast-like bone resorbing activity of myeloma plasma cells. British Journal of Haematology 173 59-69. (https://doi.org/10.1111/bjh.13922)

Vacca A, Ria R, Presta M, Ribatti D, Iurlaro M, Merchionne F, Tanghetti E \& Dammacco F 2001 Avb3 integrin engagement modulates cell adhesion, proliferation, and protease secretion in human lymphoid tumor cells. Experimental Hematology 29 993-1003. (https://doi. org/10.1016/S0301-472X(01)00674-9)

Weis SM, Stupack DG \& Cheresh DA 2009 Agonizing integrin antagonists? Cancer Cell 15 359-361. (https://doi.org/10.1016/j. ccr.2009.04.005)

Yalcin M, Bharali DJ, Lansing L, Dyskin E, Mousa SS, Hercbergs A, Davis FB, Davis PJ \& Mousa SA 2009 Tetraidothyroacetic acid (tetrac) and tetrac nanoparticles inhibit growth of human renal cell carcinoma xenografts. Anti Cancer Research 29 3825-3831.

Yalcin M, Bharali DJ, Dyskin E, Dier E, Lansing L, Mousa SS, Davis FB, Davis PJ \& Mousa SA 2010 Tetraiodothyroacetic acid and tetraiodothyroacetic acid nanoparticle effectively inhibit the growth of human follicular thyroid cell carcinoma. Thyroid 20 281-286. (https://doi.org/10.1089/thy.2009.0249)

Received in final form 2 October 2017

Accepted 10 October 2017

Accepted Preprint published online 10 October 2017 